\title{
Designing Flipped-Classes to be Taught with Limited Resources: Impact on Students' Attitudes and Learning
}

\author{
Sheri Stover \\ Wright State University \\ sheri.stover@wright.edu \\ M.A. Houston \\ Wright State University
}

\begin{abstract}
Flipped-classes in bigher education are becoming increasingly widespread due to the appeal of replacing passive lectures with active-learning communities of inquiry. This mixed methods research study follows the efforts of a professor who had limited resources as she incorporated the flipped-class design in her introductory accounting class. Class designs (lecture vs flipped-class) were compared using the community of inquiry survey, satisfaction survey, opened-ended comments, and students' final exam scores. The study found the flipped-class design had a significant impact on students' attitudes with bigher levels of community of inquiry (CoI) $(p=.002)$, teaching presence (TP) $(p=.002)$, social presence $(S P)(p=.002)$, and improved satisfaction levels $(S A T)(p=.003)$. Open-ended comments resulted in more positive comments in the flipped class design compared to the traditional lecture format (90\% vs 37\%). The higher levels of CoI predicted students' SAT score (65.4\%). The study found no significant changes in students' learning as measured by their final exam or perceptions of cognitive presence $(C P)$.
\end{abstract}

Keywords: Flipped-class, community of inquiry, course design, accounting

\section{Introduction}

Teaching introductory accounting courses can be a challenge because students enrolled have a difficult time making connections to course concepts due to their lack of relevant work experience. The majority of students taking introductory accounting courses are not accounting majors, but are taking the course to fulfill a program requirement. Thus, many students find introductory accounting courses difficult and boring (Matherly \& Burney, 2013). Most disciplines have a similar problem in that students are required to complete a difficult, quantitatively-laden course early during their freshman or sophomore years (Amato, 2013). In an effort to make an introductory accounting course more engaging to students, this faculty member redesigned her class to incorporate more active learning with a flipped-class format (Gilboy, Heinerichs, Pazzaglia, 2015; Mladenovic, 2010).

This mixed methods research study compares an instructor's efforts to redesign her introductory accounting class from a traditional lecture to the flipped-class design format. The class was first taught using a traditional lecture format, during which most of the class was presented by lecture and interspersed with application. These classes were taught in a traditional, fixed-seat auditorium style classroom. Students could read the chapter before class, but most students waited until attending the lecture before reading the chapter and completing homework problems. There were no video recordings, so if students missed class, they missed the lecture.

The instructor then redesigned her class to the flipped-class format. The instructor had no other options for classroom; therefore, the flipped course continued to be taught in a traditional fixed-seat auditorium. To create pre-class videos, the instructor used Camtasia to add audio narration to her 
PowerPoint slides. Students were expected to have watched the recordings before coming to class. There was a short quiz over the material at the start of each class. There were 16 quizzes given and only the 12 highest scores counted toward each student's final grade, counting for $10 \%$ of the grade. Most students completed their entry quizzes on their cell phones, so students were not required to purchase a laptop computer. Class time was spent predominately on application of accounting problems. Students also used their cell phones to respond to polling questions; therefore, the students did not have the additional expense of a clicker device. The instructor opted to use the free version of Poll Everywhere, so students were not hampered with the cost of purchasing a Poll Everywhere plan. This research study shows it is possible to design a flipped-class that can be taught using limited resources. This study is significant because it shows that the flipped-class format is viable for other instructors working in institutions with restricted funds or student expenditure concerns.

\section{Literature Review}

\section{Flipped-Class}

Higher education instructors are beginning to redesign their classes using the flipped-class design in an effort to replace passive lectures with a "dynamic, interactive learning environment where the educator guides students as they apply concepts and engage creatively in the subject matter" (Flipped Learning Network, 2014, p. 1). The flipped-class is defined as pedagogical methods that move the majority of information-transmission lectures out of class; replacing in-class lectures with learning activities where students work as a community of inquiry to solve problems, and require students to complete before and after class assignments to be prepared to complete the in-class activities (Abeysekera \& Dawson, 2015). The 2014 NMC Horizon Report identified flipped-classes as one of the top six technology trends in higher education expected to achieve widespread adoption within the next two years (Johnson, Adams Becker, Estrada, \& Freeman, 2014).

Flipped-classes are created on a learning culture that moves away from instructor-centered lecture to a learner-centered environment where students are working as a community of inquiry (CoI) (Flipped Learning Network, 2014). Flipped classes are grounded on the principles of the social constructivism theory that suggest students learn better by working actively and interacting with others (Vygotsky, 1978); therefore, students are required to work as groups to complete problems and assume more responsibility of their learning (Huffman, 2016).

\section{Resources to Teach Flipped Classes}

Flipped classes require students to engage in work outside class using online resources to watch prerecorded video lectures to allow students the opportunity to engage in active and collaborative learning during class. To encourage collaborative learning, some colleges and universities are moving away from the traditional, lecture-style auditorium classrooms that make interaction difficult due to the fixed seats. While there is no single flipped-class architecture, many of these new classrooms incorporate similar features. Most rooms are equipped with similar furniture consisting of round tables that seat 6-8 students with movable chairs. These rooms are usually equipped with electronic devices such as multiple computer monitors mounted throughout the room, laptop computers, microphones, and electronic attendance ID card swipe (Bateman, 2017). These specially designed flipped-classrooms are expensive for universities to build and require many resources to support (Messick, 2016). With institutions cutting expenditures on students in higher education by $21 \%$ between fiscal years 2008 through 2014 (Allison, 2016), colleges and universities are challenged in allocating funds to build, support, and maintain specially designed active learning classrooms.

Journal of the Scholarship of Teaching and Learning, Vol. 19, No. 3, June 2019. josotl.indiana.edu 
Students may also be burdened with additional expenses while enrolled in courses taught with the flipped-class enhanced classrooms. Audience response systems are frequently incorporated into flipped-classes and students are required to purchase clicker devices and/or real-time polling software to respond to instructor questions during class (Gubbiyappa, Barua, Das, Vasudeva Murthy, \& Baloch, 2016; Yu \& Wang, 2016). Students may also be required to bring laptop computers to class to complete start-of-class quizzes that encourage students to complete all pre-class video, readings, and assignments (Slomanson, 2014). These extra costs can cause financial strains on students who are trying to overcome the continuing increases in their college tuition (Flannery, 2015).

\section{Flipped Class Design Impact on Students' Attitudes- Community of Inquiry (CoI)}

A community of inquiry ( $\mathrm{CoI})$ can be defined as a learning environment where "students can take responsibility and control of their learning by negotiating meaning, diagnosing misconceptions, and challenging accepted beliefs" (Garrison, 2017, p. 24). Garrison, Anderson, and Archer (2000) developed the community of inquiry (CoI) framework to provide a "generic and coherent structure of a transactional educational experience whose core function is to manage and monitor the dynamic for thinking and learning collaboratively" (Garrison, 2017, p. 24). The CoI framework outlines the process of designing and delivering educational experiences that are deep and meaningful and grounded in the three interdependent elements of teaching presence (TP), social presence (SP), and cognitive presence (CP) (Garrison et al., 2000).

Teaching Presence. Teaching presence (TP) can be defined as "the design, facilitation and direction of cognitive and social processes for the purpose of realizing personally meaningful and educationally worthwhile learning outcomes" (Anderson, Rourke, Garrison, \& Archer, 2001, p. 5). The change in the role of the instructor in flipped-classes can decrease students' perceptions of TP due to students assuming more responsibility of their own learning (Stover \& Ziswiler, 2017). Conversely, the flipped-class can increase students' perceptions of TP because the instructor is helping students become acclimated to their new responsibility of assuming more control over their learning by working through problem-solving activities (Kim, Kim, Khera, \& Getman, 2014).

Social Presence. Social presence (SP) is defined as the "ability of participants to identify with a group, communicate openly in a trusting environment, and develop personal and affective relationships progressively by way of projecting their individual personalities" (Garrison, 2017, p. 25). Flipped-classes can have an impact on students' perceptions of SP due to new requirement of students working collaboratively to solve problems (Stover \& Ziswiler, 2017).

Cognitive Presence. Cognitive presence (CP) is defined "as the extent to which learners are able to construct and confirm meaning through sustained reflection and discourse in a critical community of inquiry" (Garrison et al., 2000, p. 11). The flipped-class format can have an impact on students' perceptions of CP due to the requirement of students assuming more control of their own knowledge creation (Mok, 2014).

\section{Flipped-Class Design Impact on Students' Attitudes- Satisfaction}

Research findings on the impact of flipped-classes on students' attitudes have been mixed. Some research studies have found students reporting higher levels of satisfaction in flipped-classes due to more active learning activities (Foertsch, Moses, Strikwerda, \& Litzkow, 2002; Lage \& Platt, 2000; Mooring, Mitchell, \& Burrows, 2016; Prince, 2004), feeling more engaged (Enfield, 2013; McLaughlin et al., 2014; Tune, Sturek, \& Basile, 2013), and having access to videos that can be reviewed as many times as desired (Brunsell \& Horejsi, 2013; Schultz, Duffield, Rasmussen, \& Wageman, 2014). However, other studies have found students' levels of satisfaction is reduced in flipped-classes due to 
students' anxiety working in groups (Doyle, 2008; Strayer, 2012; Tolman \& Kremling, 2017), disinclination toward the requirement of managing their own learning (Hagen \& Fratta, 2014), student preference to get content from instructor and not peers (Engin, 2014), and resistance to moving away from their pre-conceived beliefs that an instructor's job is to lecture to passive students (Amresh, Carberry, \& Femiani, 2013; Enfield, 2013).

\section{Flipped-Class Design Impact on Students' Learning}

Research findings on the impact of flipped-classes on students' learning has also been mixed. There have been some research studies that found flipped-classes have a positive impact on students' learning due to the requirement of needing to be prepared before class (Brunsell \& Horejsi, 2013; Enfield, 2013, Van Sickle, 2016), the ability to watch and re-watch out-of-class videos (Sahin, Cavlazoglu, \& Zeytencu, 2015), and an increase in students' long term retention (Shatto, L'Ecuyer, \& Quinn, 2017; Winquist \& Carlson , 2014). However, other research studies have shown no impact on student learning (Adams \& Dove, 2016; Baepler, Walker, Driessen, 2014; Jensen, Kummer, \& Godoy, 2015; Lape, et al, 2014; Mooring et al., 2016).

\section{Research Questions}

This research study seeks to understand the impact of designing a course using limited resources (lecture vs flipped-class) that impacts students' attitudes, learning, and experiences. Specifically, the research questions for this study are:

- RQ1: Does the course design (lecture vs flipped-class) have an impact on students' perceptions of (A) community of inquiry (CoI), (B) teaching presence (TP), (C) social presence (SP), (D) cognitive presence $(\mathrm{CP})$, and $(\mathrm{E})$ satisfaction $(\mathrm{SAT})$ ?

- RQ2: Can we predict students' level of satisfaction (SAT) based on students' levels of community of inquiry (CoI)?

- RQ3: Does the course design (lecture vs flipped-class) have an impact on students' learning as measured by their final exam scores?

- RQ4: What were students' overall experiences while in the classes?

\section{Methodology}

This mixed methods Institutional Review Board (IRB) approved research study was conducted at a medium-sized university in the Midwest. A concurrent triangulation design was used to gather data because the quantitative and qualitative data were gathered at the same time, analyzed separately, and then used to expand findings (Creswell, 2013). The majority of students $(52 \%)$ were female $(n=45)$ compared to male $(n=42)$. Students had a range of academic classifications from Freshman $(n=3)$, Sophomore $(n=56)$, Junior $(n=22)$, and Senior $(n=4)$. The majority of students $(94 \%)$ identified their age as 18-24 $(n=80), 25-30(n=2), 31-40(n=1)$, and 41-50 $(n=2)$. There were 107 students enrolled in the two classes (Class \#1 = 55; Class \#2 = 52); however, only 87 completed surveys resulting in an $81 \%$ completion rate. There were 3 records deleted (Class \#1 = 2; Class \#2=1, Table 1) because they were missing more than $5 \%$ of the data (Dong \& Peng, 2013). 
Table 1. Descriptive Data and Data Cleaning Information

\begin{tabular}{|c|c|c|c|c|c|}
\hline Class & $N$ & $\begin{array}{l}\text { Total } \\
\text { Students }\end{array}$ & $\begin{array}{l}\text { Surveys } \\
\text { Completed }\end{array}$ & $\begin{array}{ll}5 \% & \text { Missing } \\
\text { Data } & \end{array}$ & $\begin{array}{l}\text { Final } \\
\text { Records }\end{array}$ \\
\hline 1 & Lecture & 55 & 45 & 2 & 43 \\
\hline 2 & Flipped & 52 & 42 & 1 & 41 \\
\hline & Total & 107 & 87 & 3 & 84 \\
\hline
\end{tabular}

\section{Course Design}

Students in the traditional lecture class design (Class \#1) completed their readings and problem sets for homework and then attended classes where the majority of class was lecture-based (estimated $80 \%$ ). Students in the redesigned flipped-class design (Class \#2) completed their readings and some problem sets for homework. However, students in Class \#2 watched a pre-class lecture recording created by the instructor to substitute for the lecture material. Class time for Class \#2 was spent allowing students to work together to solve problem sets. Students in both classes were assessed with two midterm exams, one final exam, and three mini-exams (with lowest score being dropped). The flipped-class also included daily quizzes with the top twelve included in the final score. Students in Class \#2 used their own personal electronic devices (cell phones or laptops) to complete the daily quizzes and to respond to free Poll Everywhere polling questions. Both classes were taught in a fixedseat, auditorium classroom.

\section{Instruments}

Community of Inquiry (CoI) Survey. Arbaugh et al. (2008) developed the CoI instrument to measure students' perceptions of their levels of CoI in a learning environment. The CoI framework and survey has most often been applied to studying online and blended-learning environments; however, the CoI framework can be applied to any collaborative learning environment (Garrison, 2016). The community if inquiry (CoI) survey (Swan et al., 2008) was slightly modified to be administered to students in a face-to-face classroom environment. The CoI survey includes three subscales that measure TP (items 1-13), SP (items 14-22), and CP (items 23-34). Validation of the CoI subscales have found high levels of internal consistency with Cronbach Alpha values of 0.94 for TP, 0.91 for SP, and 0.95 for CP (Arbaugh et al., 2008).

Satisfaction Scale. The authors of this research study included questions in an attempt to measure students' level of satisfaction. The fifteen questions were designed using the semantic differential technique (Osgood, Suci, \& Tannenbaum, 1957) where students selected a 1 to 7 score between sets of bipolar adjectives (i.e.- Dissatisfaction-Satisfaction). Eight students outside the class enrollees were given a mixed up list of adjectives and asked to select the bipolar opposites for the fifteen matched pairs. Results indicated 100\% agreement on seven terms; $87.5 \%$ agreement on five terms; $75 \%$ agreement on one term; and 62.5\% agreement on two terms. Exploratory factor analysis (EFA) with principal axis factoring and varimax rotation was used to identify the underlying relationships between the survey items for the satisfaction scale to determine questions that could make up one single satisfaction grouping with primary factor loads of .4 or above (Costello \& Osborne, 2005) and no cross-loadings higher than .32 (Tabachnick \& Fidell, 2001). Results are displayed in Table 2. The satisfaction grouping resulted in twelve questions to make up the satisfaction (SAT) scale $(a=.96)$ indicating an excellent level of internal consistency (DeVellis, 2012). 
Table 2: Satisfaction Factor Matrix

\begin{tabular}{llll}
\hline Question \# & Word 1 & Word 2 & Factor \\
\hline Q54 & Frustration & Well-being & .845 \\
Q55 & Disconnected & Connected & .747 \\
Q57 & Lac of interaction & Satisfactory interaction & .725 \\
Q58 & Confusion & Clarity & .878 \\
Q59 & Defeat & Success & .877 \\
Q60 & Anxiety & Security & .775 \\
Q61 & Lack of confidence & Confidence & .789 \\
Q62 & Silence & Discussion & .652 \\
Q63 & Dissatisfaction & Satisfaction & .917 \\
Q64 & Bored & Excited & .810 \\
Q65 & Disengaged & Engaged & .823 \\
Q66 & Unmotivated & Motivated & .758 \\
\hline
\end{tabular}

\section{Results}

RQ1: Course Design (Lecture vs Flipped-Class) Impact on CoI, TP, SP, CP, and SAT

The first research question asks if the flipped-class design has an impact on students' attitudes. Students' perceptions of community of inquiry (CoI), teaching presence (TP), social presence (SP), cognitive presence (CP), and satisfaction (SAT) were compared. A Shapiro-Wilk's test $(\mathrm{p}>.05)$ (Shapiro \& Wilk, 1965) and a visual inspection of their histograms, normal Q-Q plots and box plots were examined for Class \#1 and Class \#2 to determine if the data were normally disturbed with a skewness and kurtosis z-value between -1.96 and +1.96 (Cramer, 1998). Data were determined to be normally distributed for CoI, SP, CP, and SAT scores. Differences between classes were examined using an independent samples t-test. However, data were determined not to be normally distributed for TP; therefore, the Man-Whitney $U$ test was run to determine if there were differences between students' perceptions of TP between the two groups (Table 3).

1A- CoI. Results showed a significant difference in students' perceptions of CoI, $(t(81.900)=$ $-3.181, p=.002$, Table 3). Follow up analysis showed the flipped-class design has a medium to large effect on students' perception of CoI $(d=.70)$ (Cohen, 1988). Therefore, it can be said that course design (lecture vs flipped-class) has an impact on students' perceptions of CoI.

1B-TP. Mean rank TP scores were statistically significantly higher in Class \#2 (50.73) than Class \#1 (34.65), $U=544.00, z=-3.025, p=.002$, using an exact sampling distribution for $U$ (Dineen $\&$ Blakesley, 1973). Follow up analysis showed the flipped-class design has a medium effect on students' perception of TP $\left(\eta^{2}=.11\right)$ (Cohen, 1988). Therefore, it can be said that course design (lecture vs flipped-class) has an impact on students' perceptions of TP.

Table 3: Class \#1 and Class \#2 comparison for CoI, TP, SP, CP, and SAT

\begin{tabular}{|c|c|c|c|c|c|c|c|}
\hline Class & $n$ & $M$ & $S D$ & Skewness & Kurtosis & $p$ & Effect size \\
\hline \multicolumn{8}{|c|}{ Community of Inquiry (CoI) } \\
\hline 1 & 43 & 126.14 & 17.585 & .377 & -.336 & $.002 *$ & $d=.70$ \\
\hline 2 & 41 & 138.27 & 17.352 & .094 & -.242 & & \\
\hline
\end{tabular}




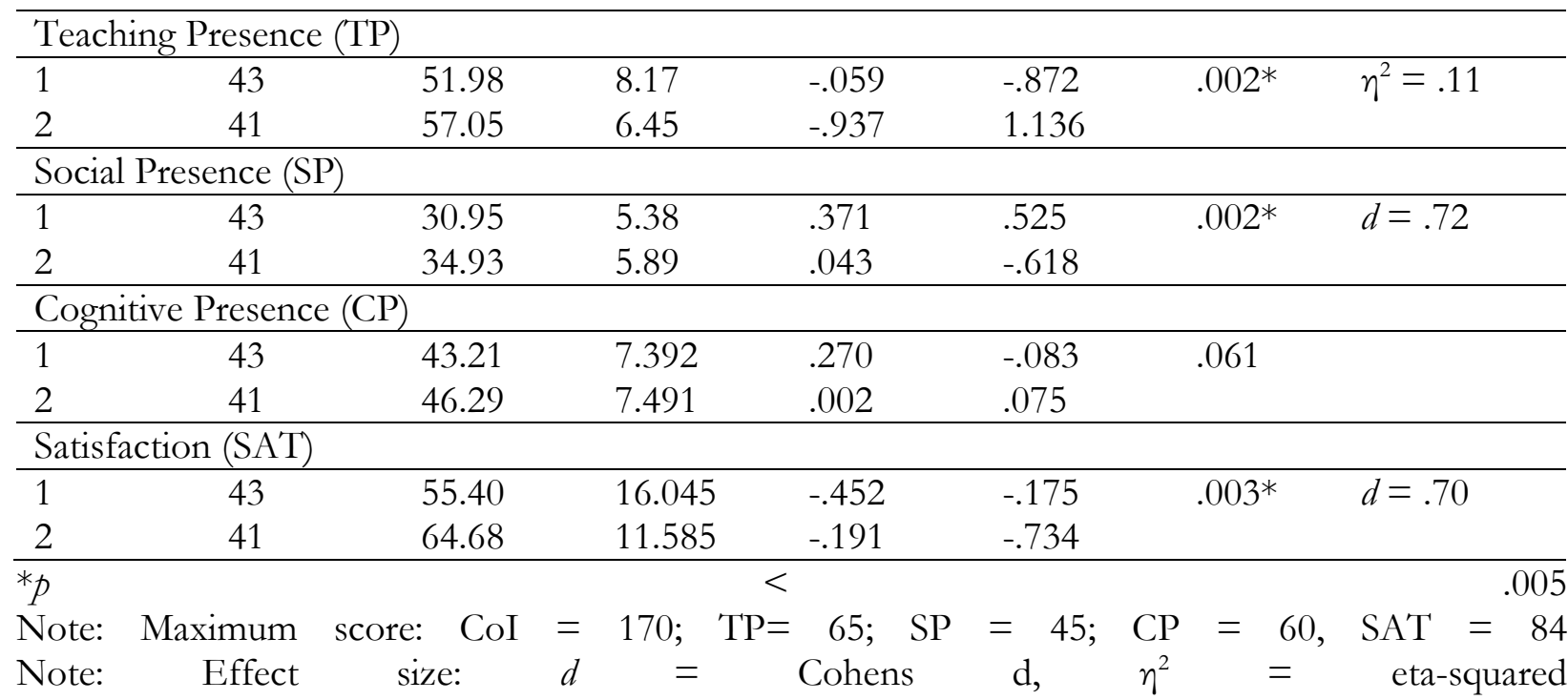

Note: Independent Samples T-Test $=$ CoI, SP, CP, and SAT; Man-Whitney U test $=$ TP

1C-SP. Results showed a significant difference in students' perceptions of SP, $(t(80.454)=$ $3.223, p=.002$, Table 3). Follow up analysis showed the flipped-class design has a medium to large effect on students' perception of SP $(d=.72)$ (Cohen, 1988). Therefore, it can be said that course design (lecture vs flipped-class) has an impact on students' perceptions of SP.

1D-CP. Results did not show a significant difference in students' perceptions of CP, $(t(81.692)$ $=-1.898, p=.061$, Table 3 ). Therefore, it cannot be said that course design (lecture vs flipped) has an impact on students' perceptions of CP.

1E SAT. Results showed a significant difference in students' satisfaction scores, $(t(76)=$ $3.052, p=.003$, Table 3). Follow up analysis showed the flipped-class design has a medium to large effect on students' perception of SAT $(d=.70)$ (Cohen, 1988). Therefore, it can be said that course design (lecture vs flipped-class) does have an impact on students' level of SAT.

\section{RQ2: Impact of CoI on SAT}

A linear regression was calculated to understand the effect of students' perceptions of community of inquiry on students' satisfaction level. Linearity and homoscedasticity were confirmed with a scatterplot. The Durbin-Watson statistic $(d=1.97)$ confirmed independence of observations. There was no evidence of multicollinearity, as assessed by tolerance values no greater than 1.0. Residuals were normally distributed as assessed by visual inspection of a normal probability plot. The linear regression established that students' level of CoI could statistically significantly predict SAT, $F(1,82)$ $=155.036, p<.0005$ (Table 4 ), accounting for $65.4 \%$ of the explained variability in students' level of SAT with an adjusted $\mathrm{R}^{2}=65 \%$, a large size effect (Cohen, 1988).

Table 4: Summary of Linear Regression Showing CoI Impact on SAT

\begin{tabular}{llllll}
\hline Variable & $B$ & $S E_{B}$ & $\beta$ & $t$ & $p$ \\
\hline Intercept & -25.502 & 6.927 & & -3.682 & $.000^{*}$ \\
CoI & .647 & .052 & .809 & 12.451 & $.000^{*}$ \\
\hline${ }^{*}<<.005$ & & & & &
\end{tabular}




\section{RQ3: Course Design (Lecture vs Flipped Class) Impact on Final Exam Score}

The third research question asks if course design (lecture vs flipped-class) has an impact on students' final exam score. The final exam was a comprehensive exam which consisted of multiple-choice questions, short-answer questions, and problems. The final exam was the exact same in both classes. Data were determined not to be normally distributed based on a Shapiro-Wilk's test ( $\mathrm{p}>$.05) (Shapiro \& Wilk, 1965) and a skewness and kurtosis z-value that was not between -1.96 and +1.96 (Table 5) (Cramer, 1998). Distributions of the final exam scores for both classes were similar, as assessed by visual inspection. Consequently, a Mann-Whitney $U$ test was run to determine if there were differences in final exam grades between classes (Dineen \& Blakesley, 1973, Table 5). Median scores were not statistically significantly different between Class \#1 and Class \#2, $U=1337, z=-.424, p=.672$. Therefore, course design (lecture or flipped-class) cannot be said to have had an impact on students' final exam scores.

Table 5: Mann-Whitney Test Comparison for Final Exam scores

\begin{tabular}{lllllllll}
\hline Class & $n$ & $\begin{array}{l}\text { Mean } \\
\text { Rank }\end{array}$ & $M$ & Skewness & Kurtosis & Z & $p$ \\
\hline 1 & 54 & 54.74 & 102.91 & -.473 & .055 & 1337 & -.424 & .672 \\
2 & 52 & 52.21 & 101.13 & -.824 & 1.735 & & & \\
\hline
\end{tabular}

Note: Maximum score for final exam $=150$ points

RQ 4: Students' Experiences

Students were asked an opened-ended question to see if they had anything additional they would like to say about their experiences while enrolled in the class. This question was asked to gain a deeper understanding of the impact of the course design (lecture or flipped-class) on students enrolled in the classes. The top three theme groupings for students' comments are summarized by class in the sections below (Table 6).

Summary of Open-Ended Comments. The open-ended comments indicate the flippedclass design had a positive impact on the students with many more positive comments than the traditional lecture class ( $90 \%$ vs 37\%). Students also indicated the flipped-class design enhanced their learning due to higher levels of engagement, opportunities for practicing problems, and access to prerecorded videos. The students in both sections had positive feelings about their instructor.

Class \#1 Traditional-Lecture. The majority of the comments for Class \#1 (lecture) were negative (12 of 19, 63\%). The largest theme were positive comments ( 7 of 19, 37\%) by students who liked their instructor with comments such as, "She is a very warm, quirky professor who is always willing to belp". The second highest theme (5 of 17, 26\%) were negative comments by students wanting more activities and/or discussion with comments such as, "There were not a lot of activities during the class. If there were more I feel like it would have helped". The third highest theme grouping ( 5 of 17, 26\%) were negative comments with students having issues with course design or instructor with comments such as, "If the only grades collected are test results and a person is naturally anxious about taking tests, this class sets them up to automatically fail'.

Class \#2 Flipped-Class. The majority of the comments for Class \#2 were positive (27 of 30, 90\%). The largest open-ended theme for Class \#2 were positive feelings (10 of 30, 33\%) about the instructor with comments such as, "Great professor. Not an easy subject for everyone, but I felt that I learned a lot'. The second highest theme grouping (7 of 30, 23\%) were positive comments where students liked

Journal of the Scholarship of Teaching and Learning, Vol. 19, No. 3, June 2019.

josotl.indiana.edu 
the flipped-class design because it helped them to learn and feel engaged with comments such as, "I wish all courses implemented [the] "flip" style of class. It was much easier to learn and apply new concepts". The third highest theme grouping (6 of 30,20\%) were positive comments where students liked the flipped-class design because they liked working problems with statements like, "Doing something over and over is how I learm best, and if I got stuck, the teacher was there to help, unlike doing homework and getting stuck/frustrated".

\section{Table 6: Open-Ended Comments Theme Groupings}

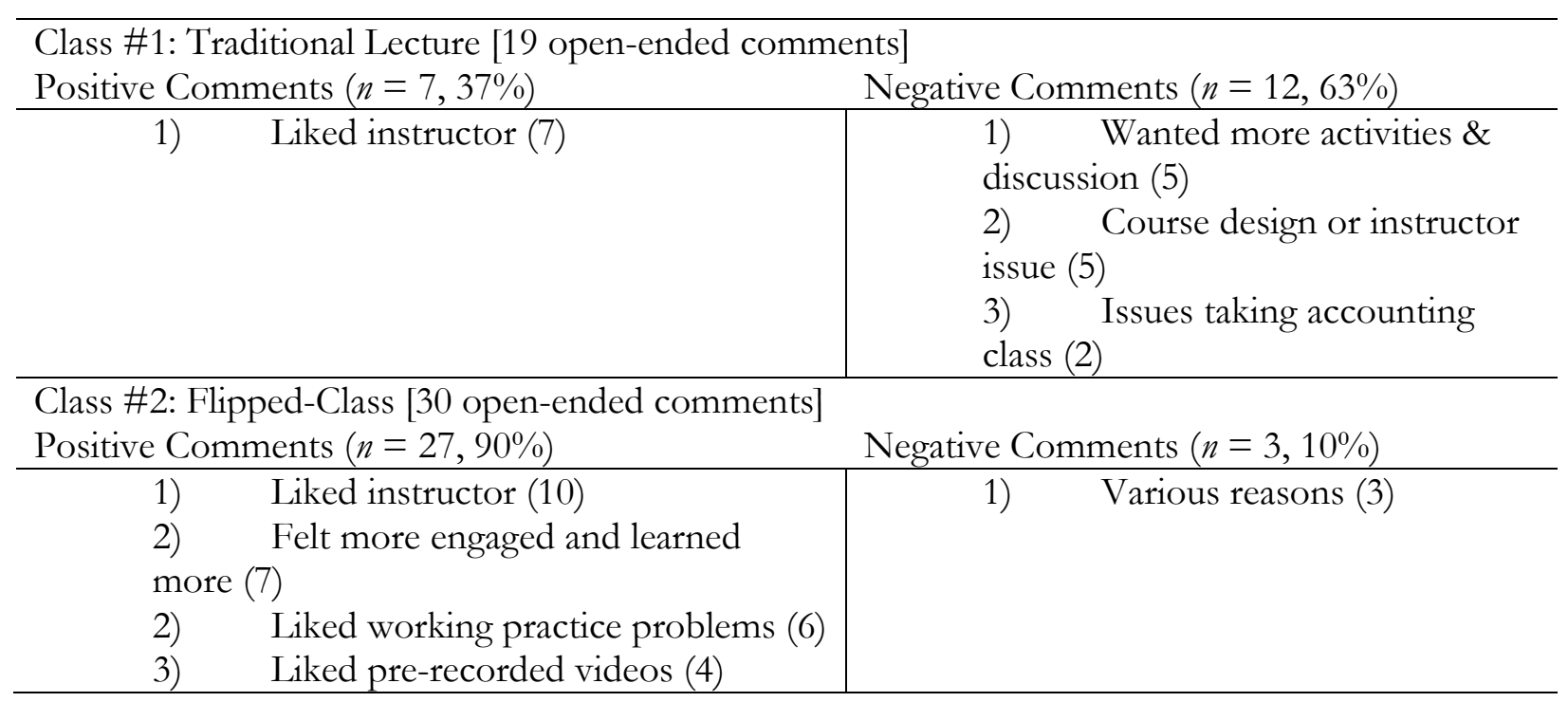

\section{Discussion}

This study has shown that it is possible to design and teach a flipped-class using limited resources. The instructor taught the flipped-class curriculum in a traditional classroom designed with tiered stadium-style fixed seating instead of moving to an active-learning classroom specifically designed with small tables to enhance group work. The instructor had students use their existing mobile devices (smart phones or laptops) to take their opening class quizzes instead of moving to a room equipped with university computers. Instead of having students purchase clickers or polling subscriptions, the instructor had students use their mobile devices (smart phone or laptop) to respond to polls through the free Poll Everywhere plan. This instructor's implementation of flipped-classes makes it much more viable for other instructors working in institutions with limited resources or student expenditure concerns.

The American Institute of CPAs (AICPA) has identified three areas that define the competencies needed by students entering the accounting profession. The framework includes functional competencies (technical skills), personal competencies (individual attributes and values), and broad business perspective competencies (understanding of internal and external business contexts) (AICPA, n.d.). Traditional lecture classes can do an adequate job in teaching students two of these competencies (functional and broad business perspective competencies). However, it is difficult for students to develop their personal competencies in lecture-oriented classrooms because they do not get an opportunity to practice skills (Agyemang \& Unerman, 2010) such as problem solving, decision making, interaction, leadership, communication, and project management (AICPA, n.d.). Classes designed with the flipped-class format will provide students the opportunities to practice their personal competency skills because they are working collaboratively with other students to 
complete problem-solving activities. Students reported significantly higher social presence $(p=.002)$ in the flipped-class because they were required to work with their classmates to solve problems. This allowed students to develop their personal competency skills identified by AICPA.

This research study shows that the flipped-class design improved students' attitudes with significantly higher levels of community of inquiry $(p=002)$, teaching presence $(p=002)$, social presence $(p=002)$, SAT $(p=003)$, and more positive comments $(90 \% \mathrm{vs} 37 \%)$. The higher levels of CoI were also found to positively predict students' satisfaction levels $(65 \%)$. The data in this study suggest that faculty designing flipped-classes where students get opportunities to collaborate will result in improved student attitudes. Students in the flipped-classroom reported feeling more engaged, learning more, and liking the practice problems.

Challenging introductory courses (such as this introductory accounting course), often serve as gateway blocks for students because they report feeling these courses are hard and/or boring and have a difficult time completing the course. Finding ways to improve students' attitudes about these courses can help improve students' experiences. This may have a positive impact on enrollment in future programs that depend on students successfully completing these difficult introductory accounting courses. Students that do not complete these gateway courses may end up dropping out of a program or enrolling in an easier program to avoid taking these "hard and/or boring" gateway courses (Killian, Huber, \& Brandon, 2012).

One of the goals of this research study was to determine if students had improved learning with the flipped-class design. Students' scores on their final examination did not show any significant gains from the traditional lecture to the flipped-class design $(p=.672)$, nor was there a significant increase in the students' cognitive presence scores $(p=061)$. However, there were several open-ended comments where students remarked on their improved learning in the flipped-class design with comments such as, "It was much easier to learn \& apply new concepts" and "Going through examples in class and learning most of the lecture outside of class really helped with learning all of the material. Probably my favorite class from a learning viempoint." Examinations do a good job of measuring short-term memory, but have a difficult time measuring students' gains in conceptual learning, personal skill development, or long-term retention. Perhaps the final exam might not be an effective tool to measure all types of learning, therefore, the researchers suggest more research on the impact of the flipped class format on student learning.

\section{Conclusion}

This research study shows it is possible to design a flipped-class that can be taught with limited resources and can significantly increase students' attitudes (CoI, TP, SP, and SAT). The study also shows that designing flipped-classes with higher levels of CoI was able to predict higher levels of student satisfaction. While there were not significant changes in students' learning (final exam or CP), the researchers suggest that the final exam might not be a suitable tool to measure students' long-term retention, skills gain, or conceptual gains. This research study is important because it shows that faculty can redesign classes that are normally considered difficult and/or boring to improve students' attitudes. The study is also important because it shows that flipped-classes can be designed to be taught in pre-existing auditorium style classrooms and do not require additional expenditures by students enrolled in the classes. This model will allow faculty with limited resources to redesign their classes to flipped-class format.

\section{Study limitations}

There are three primary limitations of this study. First, this study only included 107 students from two

Journal of the Scholarship of Teaching and Learning, Vol. 19, No. 3, June 2019.

josotl.indiana.edu 
accounting classes in one institution, making the findings not generalizable across other programs or institutions. Second, the students in this study were asked to self-report their perceptions about their own level of community of inquiry and satisfaction while participating in the class. As with all surveys where participants are asked to rate their own perceptions, there could have been response bias with influences that caused the students to move away from accurate responses (Furnham, 1986). Finally, the CoI survey was developed for use in online and blended-learning classes. The verbiage in the survey needed to be modified to be appropriate for students in a face-to-face setting. While the changes made were minor, the updates could have had an impact on the reliability of the instrument.

\section{Areas for further study}

A suggested area of further research would be to test students several months after the completion of the course to determine if the flipped-class design has an impact on students' long-term retention of information. Another suggested area of research would be to conduct this study in a different discipline since students in other disciplines also need to develop their personal competency skills such as problem solving, decision making, interaction, leadership, communication, and project management. Lastly, another suggested area of research would be to conduct this study in a classroom specifically designed for group work instead of the auditorium style seating to see if the design of the classroom has an impact on students in the areas examined in this study.

\section{References}

Abeysekera, L., \& Dawson, P. (2015). Motivation and cognitive load in the flipped classroom: Definition, rationale and a call for research. Higher Education Research \& Development, 34(1), 1 14. doi: http://dx.doi.org/10.1080/07294360.2014.934336

Adams, C., \& Dove, A. (2016). Flipping calculus: The potential influence, and the lessons learning. The Electronic Journal of Mathematics and Technology, 10(3), 154-164.

Agyeman, G. \& Unerman, J. (2010). Personal skills development and first year undergraduate accounting education: A teaching note. Accounting Education, 7(1), 87-92. doi: http://dx.doi.org/10.1080/096392898331333

Allison, T. (2016). Young invincibles student impact project. 2016 state report cards. Retrieved from http://younginvincibles.org/wp-content/uploads/2017/04/YI-State-Report-Cards2016.pdf

Amato, M. (2013, February 18). An argument against gen eds. The College Voice. Retrieved from http://thecollegevoice.org/2013/02/18/an-argument-against-gen-eds/

AICPA (American Institute of CPAs). (n.d.). Core competency framework. Retired from the AICPA web site@ https://www.aicpa.org/interestareas/accountingeducation/resources/pages/corecompetenc y.aspx

Amresh, A., Carberry, A. R., \& Femiani, J. (2013). Evaluating the effectiveness of flipped classrooms for teaching CS1. In Proceedings of Frontiers in Education Conference, FIE (pp. 733-735).

Oklahama City, OK:IEEE Xplore Digital Library. 
Anderson, T., Rourke, L., Garrison, D. R., Archer, W. (2001). Assessing teaching presence in a computer conference environment. Journal of Asynchronous Learning Networks, 5(2), 1-17.

Arbaugh, J. B., Cleveland-Innes, M., Diaz, S. R., Garrison, D. R., Ice, P., Richardson, J. D. \& Swan, K. P. (2008). Developing a community of inquiry instrument: Testing a measure of the Community of Inquiry framework using a multi-institutional sample. The Internet and Higher Education, 11(3-4), 133-136.

Baepler, P., Walker, J., Driessen, M. (2014). It's not about seat time: Blending, flipping, and efficiency in active learning classrooms. Computers \& Education, 78, 227-236.

Bateman, D. A. (2017). Flipped classrooms change student learning. San Rafael, CA: School Construction News. Retrieved from http://schoolconstructionnews.com/2017/01/10/flippedclassrooms-change-student-learning/

Brunsell, E., \& Horejsi, M. (2013). Flipping your classroom in one "take" The Science Teacher, 80(3), 8.

Cohen, J. (1988). Statistical Power Analysis for the Behavioral Sciences. Routledge. ISBN 1-134-74270-3.

Costello, A. B., \& Osborne, J. (2005). Best practices in exploratory factor analysis: Four recommendations for getting the most from your analysis. Practical Assessment Research \& Evaluation, 10(7). Available online@ http://pareonline.net/pdf/v10n7.pdf

Cramer, D. (1998). Fundamental statistics for social research. London: Routledge.

Creswell, J. W. (2013). Research design: Qualitative, quantitative, and mixed methods approaches. Thousand Oaks, CA: Sage Publications.

DeVellis, R. F. (2012). Scale development: Theory and application. Los Angeles, CA: Sage Publication.

Dineen, L. C., \& Blakesley, B. C. (1973). Algorithm AS 62: Generator for the sampling distribution of the Mann-Whitney U statistic. Applied Statistics, 22, 269-273.

Dong, Y., \& Peng, C.-Y. J. (2013). Principled missing data methods for researchers. SpringerPlus, 2(222), 1-17. . doi: 10.1186/2193-1801-2-222.

Doyle, T. (2008). Helping students learn in a learner-centered environment: A guide to facilitating learning in bigher education. Sterling, VA: Stylus.

Enfield, J. (2013). Looking at the impact of the flipped classroom model of instruction on undergraduate multimedia students at CSUN. TechTrends: Linking Research \& Practice to Improve Learning, 57(6), 14-27/

Engin, M. (2014). Extending the flipped classroom model: Developing second language writing skills through student-created digital videos. Journal of the Scholarship of Teaching and Learning, 14(5), $12-26$. 
Flannery, M. E. (2015). Who can afford a college degree today? neaToday. Washington, DC: National Education Association. Retrieved from http:// neatoday.org/2015/08/17/who-can-afford-acollege-degree-today/

Flipped Learning Network (2014). What is flipped learning? Retrieved from https:/ / flippedlearning.org/wp-content/uploads/2016/07/FLIP_handout_FNL_Web.pdf

Foertsch, J., Moses, G., Strikwerda, J., \& Litzkow, M., (2002). Reversing the lecture/homework paradigm using e-teach web-based streaming video software. Journal of Engineering Education, 91(3), 267-274.

Furnham, A. (1986). Response bias, social desirability and dissimulation. Personality and Individual Differences, 7(3), 385-400. doi: 10.1016/0191-8869(86)90014-0

Garrison, D. R., T. Anderson, T., \& Archer, W. (2000) Critical Inquiry in a Text-Based Environment: Computer Conferencing in Higher Education. The Internet and Higher Education 2(2-3): 87-105, 2000.

Garrison, D. R. (2016). Thinking collaboratively: Learning in a community of inquiry. New York, NY: Routledge.

Garrison, D. R. (2017). E-learning in the 21 st century: A community of inquiry framework for research and practice. New York, NY: Routledge.

Gilboy, M. B., Heinerichs, S., \& Pazzaglia, S. (2015). Enhancing student engagement using the flipped classroom. Journal of Nutrition Education and Behavior, 47(1), 109-114.

Gubbiyappa K.S., Barua A., Das B., Vasudeva Murthy C.R., Baloch H.Z. (2016). Effectiveness of flipped classroom with Poll Everywhere as a teaching-learning method for pharmacy students. Indian Journal of Pharmacology, 48(1), S41-S46. doi: 10.4103/0253-7613.193313

Hagen, E. J., \& Fratta, D. (2014). Hybrid learning in geological engineering: Why, how, and to what end? In M. Abu-Farsakh, X. Yu, \& L. R. Hoyos (Eds.), Proceedings of Geo-Congress 2014 Technical Papers: Geo-characterization and modeling for sustainability (pp. 3920-3929). Atlanta, GA: ASCE.

Huffman, E. (2016). Engage millennials with a flipped classroom. AICPA web site. Retrieved from https://www.aicpa.org/InterestAreas/AccountingEducation/NewsAndPublications /Pages/flipped-classroom.aspx

Killian, L. J., Huber, M. M., \& Brandon, C. D. (2012). The financial statement interview: Intentional learning in the first accounting course. Issues in Accounting Education, 21(1), 337-360.

Kim, M. K., Kim, S. M., Khera, O., \& Getman, J. (2014). The experience of three flipped classrooms in an urban university: An exploration of design principles. Internet and Higher Education, 22(2014), 37-50. doi: https://doi.org/10.1016/j.iheduc.2014.04.003 
Jensen, J. L., Kummer, T. A., \& Godoy, P. D. (2015). Improvements from a flipped classroom may simply be the fruits of active learning. CBE-Life Sciences Education, 14(1), 1-12. doi:

$10.1187 /$ cbe.14-08-0129

Johnson, L., Adams Becker, S., Estrada, V., Freeman, A. (2014). NMC Horizon Report: 2014 Higher Education Edition. Austin, Texas: The New Media Consortium. Retrieved from https://library.educause.edu/ /media/files/library/2014/1/hr2014-pdf.pdf

Lage, M., \& Platt, G. (2000). The internet and the inverted classroom. Journal of Economic Education, 31(1), 11.

Lape, N. K., Levy, R., Yong, D. H, Haushalter, K. A., Eddy, R., \& Hankel, N. (2014). Probing the inverted classroom: A controlled study of teaching and learning outcomes in undergraduate Engineering and Mathematics. Paper \#9475 presented at the $121^{\text {st }}$ ASEE Conference. Indianapolis, IN: Annual Conference \& Exposition. American Society for Engineering Education.

Matherly, M., \& Burney, L. L. (2013). Active learning activities to revitalize managerial accounting principles. American Accounting Association, 28(3), 653-680. doi: 10.2308/iace-50465

McLaughlin, J. E., Roth, M. T., Glatt, D. M., Gharkholonarehe, N., Davidson, C. A., Griffin, L. M., Esserman, D. A., \& Mumper, R. J. (2014). The flipped classroom: a course redesign to foster learning and engagement in a health professions school. Academic Medicine, 89(2), 236-243.

Messick, S. (2016). SCALE-UP statistics stand test of time. Raleigh, NC: Technician Online. Retrieved from http://www.technicianonline.com/features/article_89ca9d92-8603-11e6-8724$238 \mathrm{a} 2 \mathrm{f} 66253 \mathrm{f} . \mathrm{html}$

Mladenovic, R. (2010). An investigation into ways of challenging introductory accounting students' negative perceptions of accounting. Accounting Education, 9(2), 135-155. doi: http://dx.doi.org/10.1080/09639280010000147

Mok, H. (2014). Teaching tip: The flipped classroom. Journal of Information Systems Education, 25(1), 7 11.

Mooring, S. R., Mitchell, C. E., \& Burrows, N. L. (2016). Evaluation of a flipped, large-enrollment organic Chemistry course on student attitude and achievement. Journal of Chemical Education, 93(12), 1972-1983. doi: 10.1021/acs.jchemed.6b00367

Osgood, C. E., Suci, G. J., \& Tannenbaum, P. H. (1957). The measurement of meaning. Urbana, Il: University of Illinois Press.

Prince, M. (2004). Does active learning work? A review of the research. Journal of Engineering Education, 93(3), 223-231.

Sahin A., Cavlazoglu, B., \& Zeytuncu, Y. E. (2015). Flipping a college calculus course: A case study. Educational Technology \& Society, 18(3), 142-152. 
Schultz, D., Duffield, S., Rasmussen, S. C., \& Wageman, J. (2014). Effects of the flipped classroom model on student performance for advanced placement high school chemistry students. Journal of Chemical Education, 91(9), 1334-1339.

Shapiro, S. S., \& Wilk, M. B. (1965). An analysis of variance test for normality (complete samples). Biometrika, 52(3/4), 591-611.

Shatto, B., L'Ecuyer, K, L., \& Quinn, J. (2017). Retention of content utilizing a flipped classroom approach. Nursing Education Perspectives, 38(4), 206-208. doi: 10.1097/01.NEP.0000000000000138

Slomanson, W. R. (2014). Blended learning: A flipped classroom experiment. Journal of Legal Education, 64(1), 93-102.

Strayer, J. F (2012). How learning in an inverted classroom influences cooperation, innovation and task orientation. Learning Environments Research, 15, 171-193.

Stover, S. E., \& Ziswiler, K. (2017). Impact of active learning environments on community of inquiry. International Journal of Teaching and Learning in Higher Education, 29(3). 1-13.

Swan, K. P., Richardson, J. C., Ice, P., Garrison, D. R., Cleveland-Innes, M. \& Arbaugh, J. B. (2008). Validating a measurement tool of presence in online communities on inquiry. E-Mentor, 2(24), 1-12.

Tabachnick, B. G., \& Fidell, L. S. (2001). Using multivariate statistics. Boston, MA: Pearson Publishing.

Tolman, A. O., \& Kremling, J. (2017). Why students resist learning: A practical model for understanding and belping students. Sterling, VA: Stylus.

Tune, J. D., Sturek, M., \& Basile, D. P. (2013). Flipped classroom model improves graduate student performance in cardiovascular, respiratory, and renal physiology. Advances in Physiology Education, 37(4), 316-320.

Van Sickle, J. (2016). Discrepancies between student perception and achievement of learning outcomes in a flipped classroom. Journal of the Scholarship of Teaching and Learning, 16(2), 29-38.

Vygotsky, L. (1978). Mind in society. London: Harvard University Press.

Winquist, J. R. \& Carlson, K. A. (2014). Flipped statistics class results: Better performance than lecture over one year later. Journal of Statistics Education, 22(3), 1-10.

Yu, Z., \& Wang, G. (2016) Academic achievements and satisfaction of the clicker-aided flipped business English writing class. Educational Technology \& Society, 19(2), 298-312. 